\title{
Research Article: Knowledge and extent of adoption of recommended cultivation practices among the vegetable growers in Tamil Nadu
}

Article Chronicle: Received :

19.05.2020;

Revised:

13.06.2020;

Accepted :

15.07.2020

KeY WoRds:

Vegetable growers, Knowledge, Adoption, Production, Productivity

\section{A. Janaki Rani}

SUMMARY : The study was conducted in Chellampatti block of Madurai district in Tamil Nadu among 90 vegetable growers to assess the knowledge and extent of adoption of recommended vegetable cultivation practices. Interview schedule was constructed, pre-tested and finalized and used for collecting data. From the findings of the study it could be found that the average knowledge of vegetable farmers on recommended technologies was 74.72 per cent. Method of transplanting, recommended variety and HYV, fertilizer application, weed management, mulching and seed treatment practices were known to the farmers ranging from 75 to 90 per cent. Overall adoption level of farmers on technologies was 55.27 per cent. Soil testing, SHC recommendations, growth regulators, mulching, foliar spray, plant protection measures were having low adoption ranging from 40-48 per cent. Rise in fertilizer and pesticide prices, unavailability of timely and quality inputs, lack of knowledge to identify pest and diseases, lack of communication and training cum demonstrations on improved practices were felt by 35-45 per cent of the farmers as constraints for yield gap. The extension system have to popularize the recommended technological packages in fields through effective training, demonstrations, field visits, monitoring, etc. which helps to reduce yield gaps and thereby increasing the productivity of crops.

How to cite this article : Rani, A. Janaki (2020). Knowledge and extent of adoption of recommended cultivation practices among the vegetable growers in Tamil Nadu. Agric. Update, 15(3): 211-214; DOI : 10.15740/HAS/AU/ 15.3/211-214. Copyright@2020: Hind Agri-Horticultural Society.
Author for correspondence :

\section{A. Janaki Rani}

Human Development and Family Studies, Community Science College and Research Institute, Tamil Nadu Agricultural University, Madurai (T.N.) India

Email: janakimurugan 8 @gmail.com 